\title{
Transformation of Xanthomonas campestris pathovar campestris with Plasmid DNA
}

\author{
By D. T. ATKINS, C. E. BARBER AND M. J. DANIELS* \\ John Innes Institute, Colney Lane, Norwich NR4 7UH, UK
}

(Received 19 March 1987; revised 25 May 1987)

\begin{abstract}
Procedures for the introduction of plasmid DNA into Gram-negative bacteria have been adapted and optimized to permit transformation of the plant pathogen Xanthomonas campestris pathovar campestris with the cloning vector pK T230 and other broad-host-range plasmids. The technique involves $\mathrm{CaCl}_{2}$-induced competence and heat shock and is similar to that routinely used for Escherichia coli. Wild-type $X$. c. campestris strains appear to restrict incoming unmodified DNA, so that plasmid DNA for transformation must be prepared from $X$. $c$. campestris (into which it has previously been introduced by conjugation). To overcome this disadvantage a restriction-deficient mutant has been isolated.
\end{abstract}

\section{INTRODUCTION}

The introduction of plasmid DNA into bacterial cells by transformation is one of the most important elements of recombinant DNA technology, and optimized procedures for efficient transformation of a number of species have been devised (Saunders et al., 1984). However, considerable variation is observed in the ability of different species or strains to be transformed, and the conditions required for hitherto unstudied organisms can only be established by trial and error.

The molecular genetics of plant pathogenic bacteria has been of increasing interest in recent years (Panopoulos \& Peet, 1985; Chatterjee \& Vidaver, 1986), and recombinant DNA procedures have been applied in order to identify and characterize genes involved in pathogenicity. Transformation has been described for only a small number of pathogen species (Chatterjee \& Vidaver, 1986) and the absence of suitable procedures means that cloned genes can only be transferred into pathogens by conjugation. Not only is this more time-consuming but it also prevents the construction of non-transmissible disabled vectors, rendering biological containment of recombinant plasmids more difficult.

In this laboratory Xanthomonas campestris pathovar campestris (hereafter X.c. campestris), the causal agent of black rot of crucifers (Williams, 1980), has been used as a model for molecular genetic studies of pathogenicity (Daniels et al., 1984a, b; Turner et al., 1985; Osbourn et al., 1987). Gabriel (1984) reported transformation of $X$.c. malvacearum with an indigenous plasmid, but earlier reports of transformation with chromosomal DNA in the genus are difficult to interpret (Corey \& Starr, 1957a, b; Yamasaki et al., 1966).

In this paper we describe a simple procedure for transformation of X.c.campestris with broadhost-range plasmid DNA, similar to procedures used routinely for Escherichia coli. An endogenous restriction system limits transformation with unmodified DNA and, in order to avoid this problem, a restriction-deficient mutant has been isolated.

\section{METHODS}

Bacterial strains and culture conditions. X. c. campestris 8004 , a rifampicin-resistant derivative of strain NCPPB 1145 (Turner et al., 1984), was used for most experiments; strains BM57R [a spontaneous rifampicin- 
resistant mutant of NRRL B-1459 (Jeanes et al., 1961)] and X. c. translucens XT02 (Sawczyc, 1986) were used as noted. Bacteria were cultured at $30^{\circ} \mathrm{C}$ or $32^{\circ} \mathrm{C}$ in NYGB medium (Turner et al., 1984). E. coli ED8767 (Murray et al., 1977) was cultured at $37^{\circ} \mathrm{C}$ in NYGB or L broth (Miller, 1972).

Plasmid DNA preparation. Plasmids were isolated from E. coli or X.c. campestris strains using the alkaline lysis procedure of Birnboim \& Doly (1979) and were purified by $\mathrm{CsCl} /$ ethidium bromide buoyant density centrifugation. Crude plasmid preparations from transformants were digested with $E c \circ \mathrm{RI}$ and electrophoresed in $0.8 \%(\mathrm{w} / \mathrm{v})$ agarose gels (Maniatis et al., 1982).

Transformation procedure. A sample $(2.5 \mathrm{ml})$ of an overnight culture of $X$. c. campestris was added to $50 \mathrm{ml}$ prewarmed NYGB in a $250 \mathrm{ml}$ Erlenmeyer flask and the flask was incubated in an orbital shaker $\left(30^{\circ} \mathrm{C}, 200\right.$ r.p.m. $)$. Growth was monitored by measuring the optical density at $600 \mathrm{~nm}$ using a Unicam SP 1700 spectrophotometer. When the $\mathrm{OD}_{600}$ reached a value of $0 \cdot 4$, corresponding to a cell density of $8 \times 10^{8} \mathrm{c} . \mathrm{f}$.u. $\mathrm{ml}^{-1}$, the culture was rapidly chilled in ice and the bacteria were harvested by centrifugation at $4^{\circ} \mathrm{C}$ in a Sorvall $\mathrm{RC} 5 \mathrm{~B}$ centrifuge $(8000 \mathrm{~g}, 5 \mathrm{~min})$ The cell pellet was washed successively at $4{ }^{\circ} \mathrm{C}$ with $0 \cdot 1 \mathrm{M}-\mathrm{MgCl}_{2}$ and $0 \cdot 1 \mathrm{M}-\mathrm{CaCl}_{2}$ and finally resuspended in $2 \mathrm{ml} 0 \cdot 1 \mathrm{M}-\mathrm{CaCl}_{2}$. The suspension was kept in ice for at least $30 \mathrm{~min}$ before use. DNA samples in either 10 or $100 \mu \mathrm{l} 10 \mathrm{~mm}-\mathrm{Tris} / \mathrm{HCl}, \mathrm{pH} 8.0$, containing $1 \mathrm{~mm}-\mathrm{Na}_{2} \mathrm{EDTA}$, were dispensed in chilled sterile microcentrifuge tubes and $200 \mu \mathrm{l}$ portions of the competent cell suspension were added, rapidly mixed, and the tubes returned to the ice bath for $45 \mathrm{~min}$, before transfer to a water bath $\left(37^{\circ} \mathrm{C}, 5 \mathrm{~min}\right)$ and cooling to room temperature. The suspensions were added to $25 \mathrm{ml}$ universal bottles containing $1 \mathrm{ml} \mathrm{NYGB}$ supplemented with either rifampicin (for X.c. campestris) or spectinomycin (for X.c.translucens) and shaken $\left(30^{\circ} \mathrm{C}, 5 \mathrm{~h}\right.$ ) to permit expression of genes on the transformed plasmids, before portions were plated on NYG agar containing antibiotics appropriate to the strain and the transforming plasmid. Antibiotics were used at the following final concentrations $\left(\mu \mathrm{g} \mathrm{m}^{-1}\right)$ : chloramphenicol, $25 ;$ kanamycin, 25 ; rifampicin, 50 ; spectinomycin, 50; streptomycin, 50; tetracycline, 5 . Colonies were examined after incubation for $2 \mathrm{~d}$ at $32^{\circ} \mathrm{C}$.

Storage of competent cells. A procedure essentially as described by Morrison (1977) was used. Bacteria were harvested by centrifugation, washed successively with $0 \cdot 1 \mathrm{M}-\mathrm{MgCl}_{2}$ and $10 \mathrm{mM}-\mathrm{CaCl}_{2}$, suspended in $60 \mathrm{mM}^{-\mathrm{CaCl}} \mathrm{Cl}_{2}$ containing $15 \%(\mathrm{v} / \mathrm{v})$ glycerol, rapidly frozen in acetone/solid $\mathrm{CO}_{2}$, and stored at $-70^{\circ} \mathrm{C}$.

\section{RESULTS AND DISCUSSION}

The IncQ plasmid pK T230 (Bagdasarian et al., 1981) encoding resistance to kanamycin and streptomycin was used for most experiments. We have found that this plasmid can be stably maintained in $X$. c. campestris after introduction by conjugation from $E$. coli using the helper plasmid pRK 2073 (Leong et al., 1982), and moreover the plasmid has a moderate size (11.9 kb) rendering it suitable for transformation. The efficiency of transformation decreases with increasing plasmid size, and the commonly used broad-host-range IncP plasmids, which can also be transferred to $X$.c. campestris (Turner et al., 1984), are much larger than the IncQ family.

Initial attempts to transform $X$. c. campestris with pKT230 DNA purified from $E$. coli were unsuccessful, using the $\mathrm{CaCl}_{2}$ competence-inducing procedure described above or alternative procedures incorporating $\mathrm{RbCl}$ solution (Bagdasarian \& Timmis, 1981) or freezing and thawing (Holsters et al., 1978). We suspected that the failure was due to a restriction system in $X . c$. campestris causing degradation of the unmodified incoming DNA. Although there are no reports of restriction endonucleases produced by $X$. c. campestris many other members of the genus are known to produce these enzymes (Kessler \& Höltke, 1986). We therefore introduced pKT230 into X. c. campestris by conjugation using methods described by Daniels et al. (1984b) and Turner et al. (1984). Since conjugational transfer of plasmids proceeds via single-stranded forms the DNA is less susceptible to degradation before modification than when taken up in the double-stranded form as in transformation. Plasmid DNA, presumably modified to give protection from the putative restriction endonuclease, was purified from an $X$. c. campestris pKT230 transconjugant strain and was successfully used to transform X.c.campestris 8004 using the three methods mentioned above. Since the $\mathrm{CaCl}_{2}$ method was simpler and gave more transformants than either the $\mathrm{RbCl}$ or the freeze-thaw methods, the latter were abandoned. The $\mathrm{CaCl}_{2}$ procedure was optimized to derive the conditions described in Methods. The effects on transformation frequency of some deviations from the procedure are shown in Table 1.

The stage of growth at which bacteria are harvested affects transformation efficiency (Saunders et al., 1984). For a constant DNA concentration ( $1 \mu \mathrm{g}$ per sample) the greatest number of transformants, about 400 , was obtained when $X$. c. campestris cultures were harvested at an 
Table 1. Effect of some variations in the procedure on the efficiency of transformation of $X$. c. campestris with pKT230 DNA

Portions $(200 \mu \mathrm{l})$ of a cell suspension (about $10^{9}$ c.f.u. per portion) were transformed with $1 \mu \mathrm{g}$ modified pKT230 DNA, using the procedure described in Methods, with variations as indicated. A yield of $100 \%$ obtained under optimum standard conditions corresponded to 850 transformants per sample.

\section{Condition}

Temperature of heat shock $\left({ }^{\circ} \mathrm{C}, 5 \mathrm{~min}\right)$ :

0

30

37

42

50

Duration of heat shock

$\left(\min , 37^{\circ} \mathrm{C}\right)$ :

0

$0 \cdot 5$

2

5

10

Concn of $\mathrm{CaCl}_{2}$ used for suspending bacteria (mM): 0 (100 $\mathrm{mM}-\mathrm{MgCl}_{2}$ substituted)

\author{
Yield of transformants \\ compared with standard \\ conditions $(\%)$
}

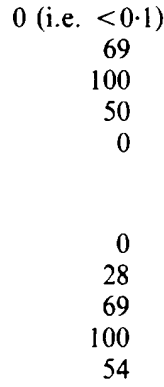

34

$\mathrm{OD}_{600}$ value of $0 \cdot 4$. However the number of transformants per cell declined steadily throughout growth. In a typical experiment bacteria were harvested for transformation at $\mathrm{OD}_{600}$ values of $0 \cdot 02,0 \cdot 1,0 \cdot 37,0 \cdot 7$ and $1 \cdot 0$ and yielded, respectively, $900,460,290,39$ and 3 transformants per $10^{9}$ cells.

The total number of transformants rose steadily as the DNA concentration increased, up to the highest level tested (10 $\mu \mathrm{g}$ per sample), but the yield of transformants per $\mu \mathrm{g}$ DNA declined when amounts greater than $0 \cdot 1 \mu \mathrm{g}$ were used.

Since $X . c$. campestris grows more slowly than $E$. coli we anticipated that a longer period of non-selective growth might be necessary after transformation to allow expression of antibiotic resistance genes, prior to plating on selective media. The number of resistant colonies which developed increased as the expression time was increased from 1 to $20 \mathrm{~h}$. However, the cell concentration also increased during this period and it was found that the number of transformants per cell reached a maximum value after $5 \mathrm{~h}$ and thereafter remained approximately constant. A $5 \mathrm{~h}$ incubation period was therefore used routinely to give the maximum yield of transformants while reducing the chance of isolating siblings. Similar numbers of transformants were recovered when samples were plated on media containing either streptomycin, kanamycin or both antibiotics. Of a random sample of 50 streptomycin-resistant colonies, $88 \%$ were also resistant to kanamycin, and of a similar sample of kanamycin-resistant colonies, $100 \%$ were also resistant to streptomycin. The $12 \%$ streptomycin-resistant, kanamycin-sensitive colonies were presumably spontaneous streptomycin-resistant mutants, which occur in $X$. c. campestris cultures at a frequency of about $10^{-9}$; spontaneous kanamycinresistant mutants have never been isolated (i.e. frequency $<10^{-11}$, M. J. Daniels, unpublished).

The presence of pKT230 in the transformants was verified by agarose gel electrophoresis of 
EcoRI-digested cleared lysates, which revealed a single DNA band with the electrophoretic mobility of authentic cleaved pK T230 DNA, and the lysates could be used to transform E. coli to resistance to streptomycin and kanamycin.

All optimization experiments were done at least twice and within experiments all sampling was in duplicate or triplicate. The yield of transformants between experiments varied by a factor of about ten, from $10^{2}$ to $10^{3}$ per $\mu \mathrm{g}$ DNA, but replicate transformations of the same batch of cells gave numbers of transformants varying by no more than $1-2 \%$. The procedure was successfully used to introduce several other broad-host-range plasmids into $X$. c . campestris, using cleared lysates from strains into which the plasmids had previously been introduced by conjugation. The plasmids were pKT210 (11.9 kb, Bagdasarian et al., 1981), pIJ3109 (14.2 kb, Osbourn et al., 1987), pLAFR3 (22 kb, B. J. Staskawicz, unpublished) and pPH1 JI (54.7 kb, Hirsch \& Beringer, 1984), and transformants were selected with streptomycin plus chloramphenicol, streptomycin, tetracycline, and chloramphenicol, respectively. It was not possible to estimate the relative transformation efficiencies of the several plasmids because the DNA concentrations in the crude lysates were unknown. No transformants were obtained with either linear or single-stranded pK T230 DNA.

$X$.c. campestris BM57R could be transformed with modified pK T230 DNA with an efficiency comparable to that of strain 8004 , but $X$. c. translucens XT02 could not, suggesting that this pathovar has a different restriction system which can cleave DNA modified by passage through X. c. campestris.

It is convenient to be able to store competent cells in a frozen state for future use. Addition of sterile glycerol (final concentration $5-20 \%, v / v$ ) to competent cells prepared by the standard method and storage at $-70^{\circ} \mathrm{C}$ was successful, but best results were obtained with the method of Morrison (1977), which allowed storage for at least two months with no loss of transforming efficiency (using pKT230) compared with freshly prepared cells. Protocols 1, 2 and 3 of Hanahan (1985) were unsatisfactory for X.c. campestris; although frozen cells retained viability, the transformation efficiency was only about $1 \%$ of that obtained with comparable cells prepared by the method of Morrison (1977).

Although the ability to transfer plasmids between $X$. c. campestris strains by a one-step transformation procedure results in a useful saving of time (3-4 d against 5-6 d) compared with the standard two-stage procedure involving transformation of $E$. coli and subsequent conjugational transfer to $X$. c. campestris (Daniels et al., 1984b), the versatility of the method would be greatly increased if the restriction barrier preventing transformation with unmodified DNA could be overcome. In the course of a number of experiments comparing pKT230 DNA samples prepared from either $X$. c. campestris or $E$. coli, no $X$. c. campestris transformants were obtained with DNA from the latter, implying that the transformation efficiency differs by a factor of $10^{3}-10^{4}$. X. c. campestris 8004 was mutagenized with ethyl methanesulphonate as described by Miller (1972) and competent cells were prepared from a subcultured pool of survivors. One-tenth of the suspension was treated with modified pK T230 DNA (purified from $X$. c. campestris) and yielded the expected number of transformants; the remainder was exposed to unmodified DNA purified from $E$. coli and yielded a single colony resistant to streptomycin and kanamycin. In order to verify that the strain was transformable with unmodified pK T230 DNA it was necessary to isolate a derivative which had lost the plasmid. This was achieved by shaking a subculture at $37^{\circ} \mathrm{C}$ for $5 \mathrm{~h}$ and then plating suitable dilutions non-selectively at $32{ }^{\circ} \mathrm{C}$ to give single colonies, 200 of which were tested for sensitivity to kanamycin and streptomycin. $X$. c. campestris is unable to grow at $37^{\circ} \mathrm{C}$, although viability is maintained for at least $20 \mathrm{~h}$, and we suspected that the stressed condition of the cells might promote plasmid loss. About $30 \%$ of the colonies were sensitive to both antibiotics and were assumed to have lost the plasmid. One plasmid-free clone, designated $8004 \mathrm{R}$, was taken for further study and was found to be transformable with equal efficiencies using either modified or unmodified pKT230 and pK T210 DNA. We believe that $8004 \mathrm{R}$ is a restriction-deficient mutant, and should be a useful working strain for future transformation experiments. The mutant retains pathogenicity to turnip seedlings, tested by the method of Daniels et al. (1984a).

Although the transformation procedure which we have described is unlikely to be efficient 
enough to use in experiments requiring mass transfer into $X$. c. campestris strains of genomic libraries containing many thousands of clones (Daniels et al., 1984b), it should considerably expedite the construction of strains carrying specific plasmids.

This work was supported by the Agricultural and Food Research Council through a grant-in-aid to the John Innes Institute and was done according to the provisions of Licence no. PHF49/105 issued by the Ministry of Agriculture, Fisheries and Food under the Plant Pests (Great Britain) Order, 1980.

\section{REFERENCES}

BagdaSARIAN, M. \& Timmis, K. N. (1981). Host : vector systems for gene cloning in Pseudomonas. In Current Topics in Microbiology and Immunology, pp. 4767. Edited by P. H. Hofschneider \& W. Goebel. Berlin \& Heidelberg: Springer Verlag.

Bagdasarian, M., LURz, R., RüCKert, B., FrankLiN, F. C. H., Bagdasarian, M. M., Frey, J. \& Timmis, K. N. (1981). Specific-purpose plasmid cloning vectors. II. Broad host range, high copy number RSF1010-derived vectors and a host-vector system for gene cloning in Pseudomonas. Gene 16, 237- 247.

Birnboim, H. C. \& Doly, J. (1979). A rapid alkaline extraction procedure for screening recombinant plasmid DNA. Nucleic Acids Research 7, 1513-1523.

Chatterjee, A. K.\& Vidaver, A. K. (1986). Genetics of pathogenicity factors : application to phytopathogenic bacteria. Adiances in Plant Pathology 4, 1-218.

COREY, R. R. \& StARR, M. P. (1957a). Genetic transformation of colony type in Xanthomonas phaseoli. Journal of Bacteriology 74, 141145.

COREY, R. R. \& STARR. M. P. (1957b). Genetic transformation of streptomycin resistance in Xanthomonas phaseoli. Journal of Bacteriolog. 74, 146-150.

Daniels, M. J., Barber, C. E., Turner, P. C., Cleary, W. G. \& Sawczyc, M. K. (1984a). Isolation of mutants of Xanthomonas campestris pv. campestris showing altered pathogenicity. Journal of General Microbiology 130, 2447-2455.

Daniels, M. J., Barber, C. F., Turner, P. C., SAWCZYC, M. K., BYrde, R. J. W. \& Fielding, A. H. $(1984 b)$. Cloning of genes involved in pathogenicity of Xanthomonas campestris pathovar campestris using the broad host range cosmid pLAFR1. EMBO Journal 3, 3323-3328.

GABRIEL, D. W. (1984). Plasmid transformation of Xanthomonas campestris pv. malvacearum. Phytopathology 74, 837.

Hanahan, D. (1985). Techniques for transformation of Escherichia coli. In DNA Cloning, vol. I, pp. 109-135. Edited by D. M. Glover. Oxford: IRL Press.

HiRsCh, P. R. \& Beringer, J. B. (1984). A physical map of pPHIJI and pJB4JI. Plasmid 12, 139-141.

Holsters, M., De Waele, D., Depicker, A., Messens, E., van Montagu, M. \& Schell, J. (1978). Transfection and transformation of Agrobacterium tumefaciens. Molecular and General Genetics 163. $181-187$.

Jeanes, A., Pittsley, J. E. \& Sentr, F. R. (1961). Polysaccharide B-1459: a new hydrocolloid polyelectrolyte produced from glucose by bacterial fermentation. Journal of Applied Polymer Science 5, 519526.
KesSler, C. \& HöltKe, H.-J. (1986). Specificity of restriction endonucleases and methylases - a review (edition 2). Gene 47, 1-153.

LeONG, S. A., Ditta, G. S. \& Helinski, D. R. (1982). Heme biosynthesis in Rhizobium. Identification of a cloned gene coding for $\delta$-aminolevulinic acid synthetase from Rhizobium meliloti. Journal of Biological Chemistry 257, 8724-8730.

Maniatis, T., Fritsch, E. F. \& Sambrook, J. (1982). Molecular Cloning: a Laboratory Manual. Cold Spring Harbor, NY: Cold Spring Harbor Laboratory.

Miller, J. (1972). Experiments in Molecular Genetics. Cold Spring Harbor, NY: Cold Spring Harbor Laboratory.

MORRISON, D. A. (1977). Transformation in Escherichia coli : cryogenic preservation of competent cells. Journal of Bacteriology 132, 349-351

Murray, N. E., Brammer, W. J. \& Murray, K. (1977). Lambdoid phages that simplify the recovery of in vitro recombinants. Molecular and General Genetics 150, 53-61.

Osbourn, A. E., Barber, C. E. \& Daniels, M. J. (1987). Identification of plant-induced genes of the bacterial pathogen Xanthomonas campestris pathovar campestris using a promoter-probe plasmid. $E M B O$ Journal 6, 23-28.

Panopoulos, N. J. \& PeEt, R. C. (1985). The molecular genetics of plant pathogenic bacteria and their plasmids. Annual Review of Phytopathology 23, 381.419.

Saunders, J. R., Docherty, A. \& Humphreys, G. O. (1984). Transformation of bacteria by plasmid DNA. Methods in Microbiology 17, 61-95.

SAWCZYC, M. K. (1986). Pathogenicity determinants of Xanthomonas campestris - a comparative study. PhD thesis, University of East Anglia, Norwich.

Tlrner, P., Barber, C. \& Daniels, M. (1984). Behaviour of the transposons $\mathrm{Tn} 5$ and $\mathrm{Tn} 7$ in Xanthomonas campestris pv. campestris. Molecular and General Genetics 195, 101-107.

Turner, P., Barber, C. \& Daniels, M. (1985). Evidence for clustered pathogenicity genes in Xanthomonas campestris pv. campestris. Molecular and General Genetics 199, 338-343.

Williams, P. H. (1980). Black rot: a continuing threat to world crucifers. Plant Disease 64, 736742.

Yamasaki, Y., Murata, N. \& SuWa, T. (1966). Restoration of lost virulence of leucine-requiring mutants of Xanthomonas oryzae by DNA-mediated transformation. Proceedings of the Japan Academy 42. $946-949$. 